\title{
Enhanced Rosmarinic Acid Production by Lavandula vera MM Cell Suspension Culture through Elicitation with Vanadyl Sulfate
}

\author{
Milen Georgiev ${ }^{\mathrm{a}}$, Sonya Kuzeva ${ }^{\mathrm{b}}$, Atanas Pavlovª ${ }^{\mathrm{a}}$ Elena Kovacheva ${ }^{\mathrm{c}}$, and \\ Mladenka Ilieva ${ }^{\text {a,** }}$ \\ a Department of Microbial Biosynthesis and Biotechnologies - Laboratory in Plovdiv, \\ Institute of Microbiology, Bulgarian Academy of Sciences, 26 Maritza Blvd., 4002 Plovdiv, \\ Bulgaria. Fax: +35928700109. E-mail: lbpmbas@yahoo.com; lbpmbas@plov.omega.bg \\ b Department of Biotechnology, University of Food Technologies, 26 Maritza Blvd., \\ 4002 Plovdiv, Bulgaria \\ c Department of Analytical Chemistry, University of Food Technologies, 26 Maritza Blvd., \\ 4002 Plovdiv, Bulgaria \\ * Author for correspondence and reprint requests \\ Z. Naturforsch. 61c, 241-244 (2006); received September 27, 2005
}

\begin{abstract}
The influence of elicitation on rosmarinic acid biosynthesis by Lavandula vera MM cell suspension culture was investigated using vanadyl sulfate as an abiotic elicitor. It was established that $12 \mathrm{~h}$ after treatment with $25 \mathrm{mg} / \mathrm{l}$ vanadyl sulfate the rosmarinic acid production was increased up to $3.92 \mathrm{~g} / \mathrm{l}$ (2.8 times higher compared to the control cultivation). No significant amounts of rosmarinic acid were detected in the culture medium in comparison with its intracellular content. However, it was observed that the extracellular content of rosmarinic acid is 3.3 times higher compared to the control variant ( $4 \mathrm{~h}$ after treatment at elicitor concentration $25 \mathrm{mg} / \mathrm{l})$.
\end{abstract}

Key words: Elicitation, Lavandula vera MM, Rosmarinic Acid, Vanadyl Sulfate

\section{Introduction}

Rosmarinic acid (RA) possesses various biological activities (antimicrobial, anti-inflammatory, antimutagenic) and also shows strong radical scavenging activities (Nakamura et al., 1998; Petersen and Simmonds, 2003). These features outline it as an interesting product for both pharmaceutical and cosmetic industries.

For enhancement of RA yields in plant cell and tissue cultures different strategies such as feeding with phenylalanine as a precursor (Hippolyte et al., 1992) and optimization of nutrient media composition and cultivation conditions in a bioreactor (Pavlov et al., 2000; Pavlov et al., 2005) were used. The elicitation with biotic (Szabo et al., 1999) and abiotic (Mizukami et al., 1993; Kim et al., 2001) elicitors was recognized as one of the most promising strategies for enhancement of RA yields, regarding to its role in the plant defense system against pathogens and herbivores (Szabo et al., 1999; Petersen and Simmonds, 2003).

According to literature data vanadyl sulfate was found as an effective elicitor for enhancement of paclitaxel, 10-deacetylbaccatin and thiarubrine A accumulation in different plant cell cultures (Bhagwath and Hjortso, 2000; Furmanowa et al.,
2000). Currently, there is no information available about the influence of vanadyl sulfate on rosmarinic acid production.

In this paper the influence of vanadyl sulfate, an abiotic elicitor, on the growth of Lavandula vera MM cell suspension culture and biosynthesis of RA are covered.

\section{Materials and Methods}

\section{Cell culture}

Lavandula vera MM cell suspension culture was used for the experiments. The culture was grown in a liquid LS nutrient medium (Linsmayer and Skoog, 1965), supplemented with $0.2 \mathrm{mg} / \mathrm{l}$ 2,4-dichlorophenoxyacetic acid and $30 \mathrm{~g} / 1$ sucrose. For the elicitation experiments optimized liquid LS medium for RA production by $L$. vera $\mathrm{MM}$ was used (Pavlov et al., 2000).

\section{Elicitor}

Vanadyl sulfate (Sigma-Aldrich) was dissolved in distilled water and then the solution was sterilized using a Millipore Stericup ${ }^{\mathrm{TM}}$ disposable filter (0.22 $\mu \mathrm{m}$, Sigma-Aldrich, USA). 


\section{Experimental design}

The experiments on the elicitation were performed in $100 \mathrm{ml}$ Erlenmeyer flasks, containing $16 \mathrm{ml}$ optimized LS medium, in the dark at $26^{\circ} \mathrm{C}$ on a shaker $(11.6 \mathrm{rad} / \mathrm{s})$. For inoculation $20 \%(\mathrm{v} / \mathrm{v})$ 7 -day-old cell suspension culture was used. Vanadyl sulfate was added to the flasks on day 11 from the beginning of the cultivation at five different final concentrations: $6.25 \mathrm{mg} / 1,12.5 \mathrm{mg} / 1,25 \mathrm{mg} / \mathrm{l}$, $50 \mathrm{mg} / \mathrm{l}$ and $75 \mathrm{mg} / \mathrm{l}$. The samples were taken and the rosmarinic acid content in the biomass and culture medium were checked at $0,4,8,12,24,36$ and $48 \mathrm{~h}$ after vanadyl sulfate addition. As a control samples without added elicitor were taken and analyzed as well.

\section{Analysis}

\section{Growth}

The growth of the cell suspension was monitored by measurement of dry biomass $\left(\right.$ at $60^{\circ} \mathrm{C}$ to constant weight) (Dixon, 1985).

Rosmarinic acid extraction and determination

Rosmarinic acid was extracted from cell biomass with $50 \%$ ethanol at $70{ }^{\circ} \mathrm{C}$ for $1 \mathrm{~h}$ (Georgiev et al., 2004). The extract was evaporated to dryness and the dry residue was dissolved in $70 \%$ ethanol. For detection of extracellular RA in the culture medium, it was evaporated to dryness and then the dry residue was dissolved in $70 \%$ ethanol. The solutions were stored at $-10^{\circ} \mathrm{C}$ for $24 \mathrm{~h}$ and the obtained precipitate was filtered off. The filtrate was used for determination of RA.

Rosmarinic acid in each sample was determined spectrophotometrically at $327 \mathrm{~nm}$ (spectrophotometer: Shimadzu UV/vis - 1240) (Lopez-Arnaldos et al., 1995).

The data presented are averages from two independent experiments; each repeated twice \pm standard deviation (SD).

\section{Results and Discussion}

In our previous experiments it was found that L. vera MM cell suspension culture is a promising producer of RA, as the achieved yields are several times higher in comparison with field plants from this species (Pavlov et al., 2000, 2005). However the elicitation of $L$. vera MM with abiotic elicitors was not investigated.

Based on our preliminary experiments it was found that the most appropriate time for addition of vanadyl sulfate is the $11^{\text {th }}$ day, which coincide with the beginning of the stationary phase of growth of $L$. vera MM cell culture. Further it was observed that the plant cell suspension of $L$. vera MM was sensitive to the elicitor, so the proper dosages of vanadyl sulfate were determined as well.

\section{Influence of vanadyl sulfate on growth of L. vera MM cell suspension}

After $4 \mathrm{~h}$ a decrease in the accumulated dry biomass was observed, as a response to all studied concentrations of the elicitor (Fig. 1), which probably was due to a defense response (Chen and Chen, 2000). Further, $8 \mathrm{~h}$ after the elicitor treatment this effect was overcome and the quantities of accumulated biomass were enhanced. This enhancement was most significant when the cells were treated with $6.25 \mathrm{mg} / \mathrm{l}$ and $12.5 \mathrm{mg} / \mathrm{l}$ vanadyl sulfate (about 2-6\% enhancement), while for the higher elicitor concentrations $(50 \mathrm{mg} / \mathrm{l}$ and $75 \mathrm{mg} /$ 1) the amounts of accumulated biomass were lower compared to the non-elicited cells (about 4-12\% decrease) (Fig. 1).

\section{Influence of vanadyl sulfate on rosmarinic acid} accumulation in the cells and on its secretion in the culture medium

For all concentrations under study the addition of vanadyl sulfate provoked significant enhancement of intracellular rosmarinic acid production, but the produced RA amounts and the time for

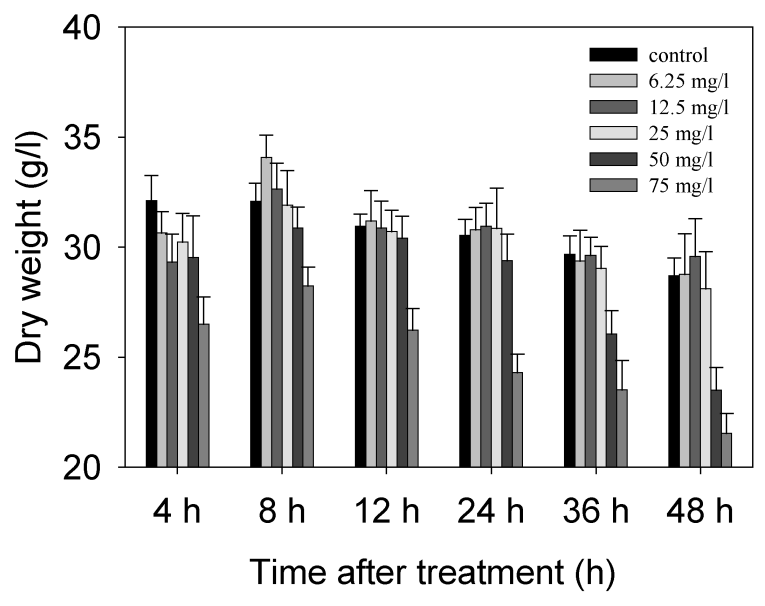

Fig. 1. Time course of growth of $L$. vera MM cell suspension after treatment with different concentrations of vanadyl sulfate (the elicitor was added on day 11 of cultivation). Bars represent standard deviation. 


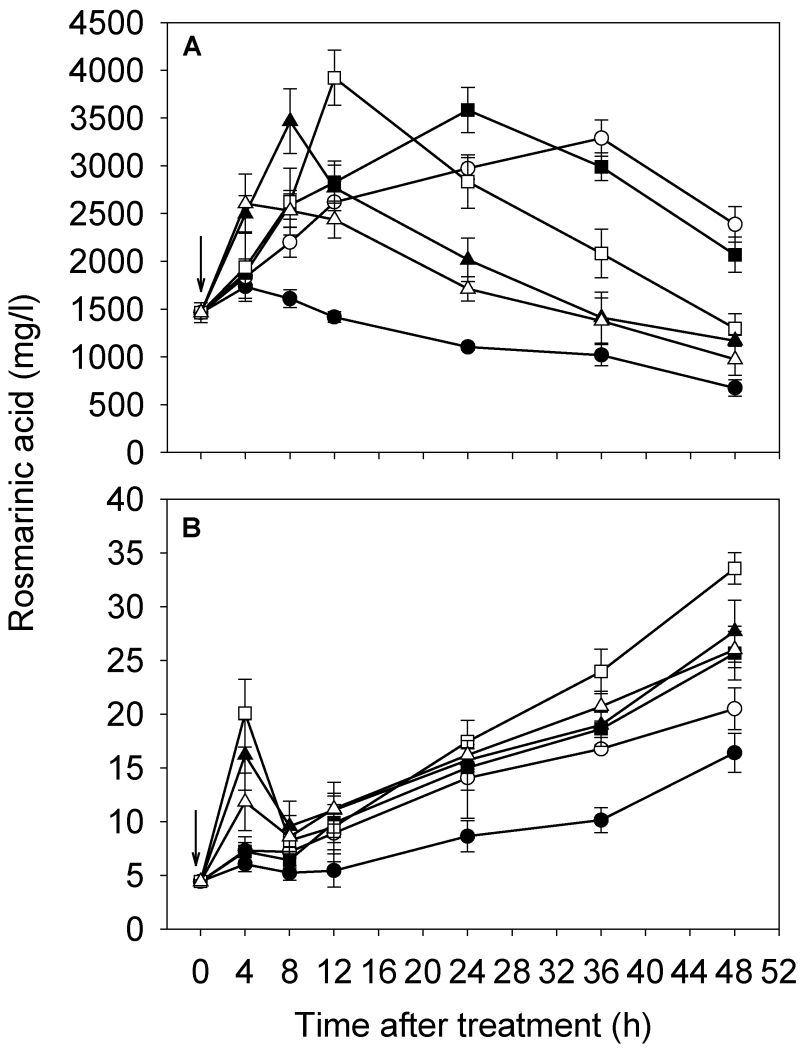

Fig. 2. Time course of rosmarinic acid content in cell biomass (A) and in culture media (B) of L. vera MM cell suspension culture after addition of different concentrations of vanadyl sulfate. Symbols: $\downarrow$ time of elicitor addition (on day 11 of cultivation); (•)

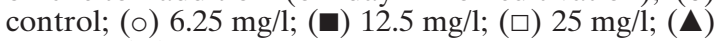
$50 \mathrm{mg} / \mathrm{l} ;(\triangle) 75 \mathrm{mg} / \mathrm{l}$. Bars represent standard deviation. their achievement were different (Fig. 2A). The maximum in RA production appeared when the cells were treated with $25 \mathrm{mg} / \mathrm{l}$ vanadyl sulfate (about $3.9 \mathrm{~g} / \mathrm{l}$ ). In comparison to the non-elicited cells (control cultivation) this yield is 2.8 times higher and the achieved productivity of $339 \mathrm{mg} /$ $(1 \cdot d)$ rosmarinic acid is one of the highest reported so far. No significant amounts of RA were detected in the culture medium in comparison with its intracellular content (Fig. 2B) and the possible reason for this is the presence of active peroxidases in it, which rapidly destroy RA (Szabo et al., 1999). Four hours after the treatment with elicitor, the detected amounts of rosmarinic acid in the culture medium were between $7.3 \mathrm{mg} / \mathrm{l}$ and $20.1 \mathrm{mg} / \mathrm{l}$
(Fig. 2B), which is $1.2-3.3$ times higher, compared to non-elicited cells. This fact revealed possibilities for further two phase cultivation of L. vera MM cells with the aim to "capture" these amounts of RA and to save it from destructive peroxidases (Pavlov et al., 2001). Further from $12 \mathrm{~h}$ to $48 \mathrm{~h}$ after the addition of vanadyl sulfate the determined amounts of extracellular RA were about $34 \mathrm{mg} / \mathrm{l}$; this enhancement is probably due to the lysis processes and connected with this leakage of $\mathrm{RA}$ in the culture medium.

\section{Acknowledgements}

We thank Mr. Nikolay Krumov for linguistic improvement of the manuscript. 
Bhagwath S. G. and Hjortso M. A. (2000), Statistical analysis of elicitation strategies for thiarubrine A production on hairy root cultures of Ambrosia artemisifolia. J. Biotechnol. 80, 159-167.

Chen H. and Chen F. (2000), Effects of yeast elicitor on the growth and secondary metabolism of a hightanshinone-producing line of the $\mathrm{Ti}$ transformed Salvia miltiorrhiza cells in suspension culture. Process Biochem. 35, 837-840.

Dixon R. A. (1985), Isolation and maintenance of callus and cell suspension cultures. In: Plant Cell Culture - a Practical Approach (Dixon R. A., ed.). IRL, Oxford, pp. 1-20.

Furmanowa M., Oledzka H., Syklowska-Baranek K., Jozefowicz J., and Gieracka S. (2000), Increased taxane accumulation in callus cultures of Taxus cuspidata and Taxus x media by some elicitors and precursors. Biotechnol. Lett. 22, 1449-1552.

Georgiev M., Pavlov A., and Ilieva M. (2004), Rosmarinic acid production by Lavandula vera MM cell suspension: Temperature effect. Biotechnol. Lett. 26, $855-856$.

Hippolyte I., Marin B., Baccou J. C., and Jonard R. (1992), Growth and rosmarinic acid production in cell suspension cultures of Salvia officinalis L. Plant Cell Rep. 11, 109-112.

Kim H. K., Oh S.-R., Lee H.-K., and Huh H. (2001), Benzothiadiazole enhances the elicitation of rosmarinic acid production in a suspension culture of Agastache rugosa O. Kuntze. Biotechnol. Lett. 23, 55-60.

Linsmayer E. M. and Skoog F. (1965), Organic growth factor requirements of tobacco tissue cultures. Physiol. Plant. 18, 100-127.
Lopez-Arnaldos T., Lopez-Serrano M., Ros Barcelo A., Calderon A. A., and Zapata J. M. (1995), Spectrophotometric determination of rosmarinic acid in plant cell cultures by complexation with $\mathrm{Fe}^{2+}$ ions. Fresen. J. Anal. Chem. 351, 311-314.

Mizukami H., Tabira Y., and Ellis B. E. (1993), Methyl jasmonate-induced rosmarinic acid biosynthesis in Lithospermum erythrorhizon cell suspension cultures. Plant Cell Rep. 12, 706-709.

Nakamura Y., Ohto Y., Murakami A., and Ohigashi H. (1998), Superoxide scavenging activity of rosmarinic acid from Perilla frutescens Britton var. acuta $\mathrm{f}$ viridis. J. Agric. Food Chem. 46, 4545-4550.

Pavlov A. I., Ilieva M. P., and Panchev I. N. (2000), Nutrient medium optimization for rosmarinic acid production by Lavandula vera MM cell suspension. Biotechnol. Progr. 16, 668-670.

Pavlov A., Ilieva M., and Mincheva M. (2001), Release of rosmarinic acid by Lavandula vera MM cell suspension in two-phase culture systems. World J. Microbiol. Biotechnol. 17, 417-421.

Pavlov A. I., Georgiev M. I., Panchev I. N., and Ilieva M. P. (2005), Optimisation of rosmarinic acid production by Lavandula vera MM plant cell suspension in a laboratory bioreactor. Biotechnol. Progr. 21, 394-396.

Petersen M. and Simmonds M. S. J. (2003), Rosmarinic acid. Phytochemistry 62, 121-125.

Szabo E., Thelen A., and Petersen M. (1999), Fungal elicitor preparations and methyljasmonate enhance rosmarinic acid accumulation in suspension cultures of Coleus blumei. Plant Cell Rep. 18, 485-489. 